\title{
PERJANJIAN PENYERAHAN WILAYAH UTARA BORNEO 1865, 1877 DAN 1878: TINJAUAN AWAL TERHADAP PERBANDINGAN INTIPATI PERJANJIAN
} North Borneo Territory Surrender Agreements 1865, 1877 And 1878: A Preliminary Review of The Comparison of The Contents in The Agreement

\author{
${ }^{1}$ DG. JUNAIDAH BINTI AWANG JAMBOL \\ ${ }^{2}$ BASZLEY BEE BIN BASRAH BEE
${ }^{1 \& 2}$ AFakulti Sains Sosial dan Kemanusiaan, Universiti Malaysia Sabah, Jalan UMS, 88400 Kota Kinabalu, Sabah. 'dgjunaidah@ums.edu.my; ${ }^{2}$ baszley@ums.edu.my \\ Tarikh dihantar: 29 Mac 2021 / Tarikh diterima: 29 Jun 2021
}

\begin{abstract}
Abstrak Makalah ini merupakan satu usaha untuk membahaskan semula pandangan mengenai perjanjian-perjanjian 1865, 1877 dan 1878 tentang penyerahan wilayah utara Borneo oleh Kesultanan Brunei dan Kesultanan Sulu kepada British North Borneo (Chatered) Company (BNBC) yang diwakili oleh Overbeck dan Alfred Dent. Sumber primer sedia ada telah diinterpretasi semula oleh penulis dalam perspektif yang baharu. Dihujahkan bahawa perjanjian penyerahan wilayah utara Borneo pada tahun 1865, 1877 dan 1878 yang dilakukan oleh Kesultanan Brunei dan Kesultanan Sulu ini telah menghasilkan suatu peristiwa yang dilihat daripada dua dimensi yang berbeza di dalam pensejarahan Borneo Utara. Kajian lepas banyak diteluri dengan sumber dokumentasi barat sehingga mengabaikan sumber tempatan yang dianggap bersifat berat sebelah terutamanya apabila Kesultanan Brunei menafikan penyerahan sebahagian wilayah utara Borneo kepada Kesultanan Sulu. Namun pada masa yang sama Kesultanan Sulu tetap meneguhkan pendiriannya bahawa telah berlaku penyerahan tersebut kepadanya dengan menggunakan perjanjian 1878 sebagai pengesahan. Dapatan kajian menunjukkan bahawa perjanjian penyerahan wilayah utara Borneo 1865, 1877 dan 1878 berlaku disebabkan oleh kegagalan Kesultanan Brunei dan Kesultanan Sulu untuk mengawal politik pentadbiran di tanah jajahan masing-masing sehingga terpaksa melakukan penyerahan wilayah mengikut terma perjanjian Barat bagi memastikan kedua-dua buah Kesultanan tersebut mampu untuk terus survival. Kajian ini juga mendapati bahawa kepelbagaian tafsiran terhadap terjemahan kandungan perjanjian juga turut memberikan implikasi besar terhadap kefahaman masyarakat sehingga menimbulkan pelbagai spekulasi dan
\end{abstract}


pertikaian yang berterusan sehingga kini. Justeru itu, makalah ini akan cuba untuk menganalisis perbandingan perjanjian penyerahan Borneo Utara pada tahun 1865, 1877 dan 1878 bagi merungkaikan kebenaran peristiwa sejarah antara Kesultanan Brunei dan Kesultanan Sulu sehingga membawa kepada berlakunya penyerahan wilayah ini secara total kepada BNBC.

Kata kunci: Utara Borneo, penyerahan, Kesultanan Brunei, Kesultanan Sulu, BNBC.

Abstract This paper is an attempt to the explanation of the cession of the northern territory of Borneo by the Sultanate of Brunei and the Sultanate of Sulu to the British North Borneo (Chatered) Company (BNBC) represented by Overbeck and Alfred Dent. Existing primary sources has been reinterpreted by the authors in a new perspective. It is argued that the treaties of surrender of the northern territories of Borneo in 1865, 1877 and 1878 made by the Sultanate of Brunei and the Sultanate of Sulu have produced an event seen from two different dimensions in the history of North Borneo. Past studies have been heavily influenced by western documentations so that ignoring local sources is considered biased especially when the Sultanate of Brunei denies the surrender of a part of North Borneo territory to the Sultanate of Sulu. Yet at the same time the Sultanate of Sulu maintained its position that there had been the surrender of the northern province of Borneo to it by using the 1878 treaty as confirmation. The findings of the study showed that the northern Borneo territorial agreements of 1865, 1877 and 1878 occurred due to the failure of the Sultanate of Brunei and Sulu to control administrative politics in their respective colonies so that they had to surrender the territories in accordance with the terms of the Western agreement to ensure continuous survival. This study also found that the variety of interpretations on the translation in the content of the agreement also has significant implications on the understanding of society, leading to various speculations and disputes up to this day. Therefore, this paper will attempt to analyze the comparison of North Borneo cession agreements in 1865, 1877 and 1878 to unravel the truth of historical events between the Sultanate of Brunei and the Sultanate of Sulu leading to the total surrender of this territory to $B N B C$.

Keywords: North Borneo, concession, Brunei, Sulu, BNBC. 


\section{PENGENALAN}

Pada abad ke-18, aktiviti perdagangan menjadi nadi utama kepada pihak Barat. Pihak British telah menggunakan kelebihan mereka memonopoli perdagangan di timur dan barat. Pada abad ini juga turut menyaksikan Brunei mempunyai hubungan perdagangan dengan bangsa Eropah berdasarkan prinsip negosiasi dan tolak-ansur. Meskipun pada peringkat awal perjanjian dengan pihak Amerika didasari oleh kelebihan geostrategik Brunei namun, kebanyakan sejarawan tidak menolak bahawa keinginan tersebut didorong oleh perebutan kuasa Eropah untuk memiliki wilayah-wilayah yang kaya dengan sumber mentah serta kemudahan pertahanan yang membolehkan kegiatan komersial dijalankan dengan lancar.

Perjanjian penyerahan yang wujud pada tahun 1865, 1877 bersifat lebih jelas maksudnya dari segi intipati perjanjian penyerahannya berbanding dengan penyerahan 1878. Hal ini kerana penyerahan fasa kedua banyak menimbulkan keraguan dari segi kandungan perjanjiannya yang disifatkan banyak berpihak kepada pihak Barat. Isu perjanjian ini juga turut mendapat pelbagai tafsiran yang agak rambang dalam konteks politik semasa sehingga menimbulkan satu perkara kompleks yang mencabar pemahaman sejarah dan aplikasi undang-undang semasa. Persepsi ini juga cuba untuk meninjau tentang kelemahan dan kelompangan di dalam dokumen perjanjian 1865, 1877 dan 1878 yang dilihat sebagai tidak adil kepada Kesultanan Brunei dan Sulu kerana dianggap lebih memihak kepada Barat. Perdebatan ini berpunca daripada penyerahan wilayah pantai timur laut Borneo oleh Kesultanan Sulu kepada British yang dianggap sebagai pajakan sementara dan bukannya bersifat kekal. Sebaliknya daripada perspektif sejarah undangundang, keabsahan penyerahan wilayah sebenarnya bergantung penuh kepada isi kandungan perjanjian yang telah dipersetujui dan ditandatangani oleh kedua-dua belah pihak.

\section{PERJANJIAN SULTAN BRUNEI DENGAN CHARLES LEE MOSES DAN JOSEPH TORREY 1865}

Pada awal abad ke-19, Amerika Syarikat telah menjadi negara yang paling aktif dalam mengembangkan aktiviti perdagangan di Asia Tenggara. Pada 
ketika itu, Amerika Syarikat telah menghantar pelbagai misi diplomatik ke Jepun, China, Siam dan Borneo untuk tujuan menjalinkan hubungan dengan negara-negara di Asia Timur dan Asia Tenggara (D.S Ranjit Singh, 2003: 113; Graham Irwin, 1986: 244). Pada tahun 1850, perjanjian persahabatan dan perdagangan di antara kerajaan Brunei dengan pihak Amerika Syarikat telah berjaya dimeterai selepas usul pertama ditolak oleh Kesultanan Brunei. Di bawah perjanjian ini, pihak Amerika Syarikat berjanji untuk memberikan perlindungan terhadap kerajaan Brunei (Graham Irwin, 1986: 244-245; H.G.Keith, 1980: 5).

Pada bulan Julai 1865, Charles Lee Moses yang dilantik menjadi Konsul Amerika Syarikat di Brunei telah tiba di Borneo untuk memulakan tugasnya. Charles Lee Moses telah mengambil kesempatan tersebut untuk mendapatkan peluang yang ada dengan menekankan bahawa dia bertindak sebagai wakil rasmi kerajaan Amerika Syarikat. Dengan cara tersebut, beliau telah berjaya memujuk Sultan Brunei dan Pengiran Temenggung supaya memperkenankan pajakan persendirian selama 10 tahun ke atas sebahagian besar kawasan Pantai Barat di Borneo Utara iaitu dari wilayah Sungai Sulaman sehingga ke Sungai Paitan termasuk Kepulauan Banggi, Balabak dan Palawan (Nicholas Tarling, 1971: 169-170; Graham Irwin, 1986: 244; D.S Ranjit Singh, 2003: 113-114). Kemudian, Charles Lee Moses juga berjaya mendapatkan perjanjian kedua konsesi tanah melalui Pengiran Temenggung yang memiliki wilayah Benoni, Kimanis, Paitan, Sugut, Bongaya, Labuk, Sandakan, Kinabatangan, Cagayan dan Moming dengan bayaran sewa tahunan keseluruhannya sebanyak $\$ 9,500$ (CO 874/2).

Perlu diketahui bahawa perlantikan Charles Lee Moses sebagai konsul di Brunei tidak dibayar gaji oleh pihak kerajaan Amerika Syarikat. Namun, beliau masih dibenarkan oleh pihak Amerika Syarikat untuk menjana kewangan sendiri melalui aktiviti perdagangan sepanjang berada di Brunei. Perkara ini termaktub di dalam perjanjian perdagangan dan persahabatan di antara Amerika Syarikat dengan Sultan Brunei untuk membenarkan konsul Amerika berdagang secara bebas di Brunei. Sebelum Charles Lee Moses tiba di Brunei, beliau telah mengalami tahap keberhutangan yang sangat tinggi untuk menanggung kos pelayarannya ke Borneo. Menurut konsul Jeneral British Henry Bulwere, Charles Lee Moses mengalami masalah 
kewangan yang teruk sehingga tidak mampu untuk membayar tambang pelayarannya ke Borneo. Oleh sebab itu, beliau telah melakukan pajakan tanah daripada Sultan Brunei bagi mengelakkan keluarganya hidup dalam kemiskinan. Pada 11 Ogos 1865, beliau telah memperolehi konsesi tanah daripada Sultan Brunei dan terus bergegas ke Hong Kong untuk melakukan pindah milik pajakan tanah kepada Joseph William Torrey, Thomas Bradley Harris dan Wo Hang pada 9 September 1865 (H.G Keith, 1980: 7). Sewaktu Charles Lee Moses berada di Hong kong, beliau bersama rakan kongsinya telah menubuhkan American Trading Company (ATC) bagi menjalankan perniagaan perdagangan am. ${ }^{1}$ Pada 16 November 1865, Charles Lee Moses telah belayar ke Brunei untuk memaklumkan kepada Sultan Brunei dan pengiran Temenggung tentang pemindahan milik konsesi tanah tersebut. Pada 24 November 1865, Sultan Brunei dan pengiran Temenggung telah menerima perkhabaran daripada Charles Lee Moses tentang pemindahan pemilikan konsesi tanah kepada rakan kongsinya Joseph Torrey, Thomas Harris dan Wo Hang. Beliau kemudiannya telah bertindak mendaftarkan penukaran nama milikan konsesi tanah tersebut di kedutaan Brunei pada 25 November 1865 (CO 874/4; CO 874/5; FO 12/32). Hakikatnya, Charles Lee Moses sangat mudah untuk mendapatkan tanah jajahan Brunei dan memindah milik sewaan kerana perjanjian konsesi tanah yang telah dimeterai antara Charles Lee Moses dengan Sultan Brunei serta Pengiran Temenggung tersebut didapati sangat longgar.

Terdapat beberapa isu yang meragukan di dalam perjanjian pajakan ATC yang dilakukan oleh Charles Lee Moses dengan Sultan Brunei dan Pengiran Temenggung. Hal ini kerana berdasarkan isi kandungan perjanjian pajakan tersebut, Sultan Abdul Momin telah memajakkan wilayahnya di kawasan Pantai Barat utara Borneo kepada Charles Lee Moses atau warisnya atau orang yang dilantiknya dari Sungai Sulaman ke Sungai Paitan yang mengandungi 21 buah daerah. Kelompangan di dalam perjanjian ini dapat dilihat apabila wujud kenyataan di dalam perjanjian pajakan versi Inggeris a new contract shall be made yang boleh disifatkan di dalam perundangan yang mempunyai dua maksud, iaitu pertama; selepas tamat tempoh pajakan selama 10 tahun, Charles Lee Moses atau warisnya atau wakil yang dilantiknya perlu membuat perjanjian dengan Sultan Brunei terlebih dahulu sebelum meneruskan perjanjian baharu. Maksud kedua pula menyifatkan bahawa 
Charles Lee Moses atau warisnya atau wakil yang dilantiknya berhak untuk meneruskan perjanjian tersebut secara automatik sepertimana perjanjian asal tanpa perlu merujuk dan memaklumkan kepada Sultan sebagai pemiliknya. Hal ini bermakna perjanjian ini akan kekal selama-lamanya. Namun begitu, Charles Lee Moses tidak bertindak memanipulasi kelemahan perjanjian tersebut dan menggunakan maksud yang pertama bagi meneruskan perjanjian pajakannya dengan Sultan Brunei. Selain itu, perjanjian pajakan di dalam versi Inggeris juga didapati lebih bersifat semasa. Perkara ini terbukti apabila wujud perubahan $^{2}$ dari segi pembayaran tahunan konsesi yang memperlihatkan kedua-dua belah pihak telah bersetuju untuk melakukan pembayaran tahunan secara berperingkat-peringkat dalam tempoh 10 tahun berbanding dengan sebelumnya. Lantaran itu, dapatlah dinilaikan bahawa Sultan Brunei tidak bertindak tegas dalam hal ehwal pembayaran konsesi tanah sehingga baginda kehilangan banyak wilayahnya di utara Borneo pada tahun-tahun berikutnya (CO 874/2; CO 874/6; CO 874/13).

Isu seterusnya adalah berkaitan dengan bahasa. Apabila pihak ATC dan Setiausaha Gabenor Amerika Syarikat menghantar surat kepada Sultan Brunei, tempoh masa yang diperlukan untuk menterjemahkannya agak lama. Begitu juga dengan penterjemahan surat daripada Sultan Brunei kepada pihak ATC dan Setiausaha Gabenor Amerika Syarikat, mereka memerlukan masa sebulan untuk menterjemahkan bahasa jawi ke dalam bahasa Inggeris. Keadaan ini menyebabkan sebarang tindakan tidak dapat dilaksanakan serta merta dan mengambil masa lama untuk membuat keputusan tentang sesuatu perkara penting yang memerlukan tindakan segera (H.G Keith, 1980: 89-92). Isu pajakan ini mencapai kemuncaknya apabila Joseph Torrey mengetahui perancangan Charles Lee Moses untuk menggagalkan pembayaran pajakan ATC untuk membolehkan beliau menjualkannya semula kepada orang lain. Di sebalik tindakan Charles Lee Moses ini sebenarnya beliau ingin mendapatkan pembayaran daripada hasil pemajakan tersebut daripada saudagar lain memandangkan Joseph Torrey tidak dapat melunaskan pembayarannya kepada Sultan Brunei. Joseph Torrey juga menyedari bahawa Charles Lee Moses boleh melakukan rundingan secara terus dengan Sultan Brunei bagi mendapatkan pengesahan Sultan. Oleh yang demikian, Joseph Torrey telah meminta Thomas Harris berjumpa dengan Sultan Brunei bagi mendapatkan persetujuan tentang pajakan tersebut dan 
seterusnya menggagalkan rancangan Charles Lee Moses (FO 12/33). Sultan Brunei dan Pengiran Temenggung tidak mempunyai kawalan terhadap tanah pajakan yang diserahkan kepada kuasa asing kerana peraturan yang tidak jelas dan tegas dalam pembayaran. Pajakan wilayah yang memberikan keuntungan kepada Sultan Brunei dan Pengiran Temenggung hanyalah Kimanis dan Benoni.

Pada bulan November 1865, Joseph William Torrey telah ke Brunei untuk ditabalkan sebagai "Raja Ambong dan Marudu" serta diiktiraf sebagai pemerintah tertinggi bagi keseluruhan wilayah yang dikuasainya. Di bawah tunjuk ajar Torrey, sebuah ladang kecil dan petempatan pedagang telah ditubuhkan di pantai Teluk Kimanis dengan kakitangan yang terdiri daripada 10 orang bangsa Amerika dan 60 orang buruh Cina. Perusahaan ini dijalankan melalui modal pinjaman sementara dari komuniti saudagar Cina di Labuan (Wright L.R.1970: 116). Walau bagaimanapun, pada tahun 1866, petempatan pedagang tersebut gagal untuk dimajukan dan semua aktiviti pertanian di Kimanis terpaksa dihentikan. Semenjak itu, ATC hanya menjalankan usaha perdagangan berkala di Pantai Barat Borneo. Dalam menghadapi permasalahan tersebut, Torrey dan rakan kongsinya tetap berusaha mengekalkan hak mereka di utara Borneo kerana masih berharap akan memperolehi keuntungan darinya. Bagi pihak Charles Lee Moses pula beliau tetap berusaha untuk mendapatkan bantuan kewangan dari kerajaan Austria tetapi gagal kerana kerajaan tersebut menganggap beliau hanya bertindak atas kepentingan sendiri (Graham Irwin, 1986: 245; D.S Ranjit Singh, 2003: 113-114).

Kegagalan Joseph Torrey memajukan Kimanis menyebabkan beliau berpindah ke Hong Kong. Sewaktu berada di Hong Kong, Joseph Torrey telah menjadi pengurus kilang penapis gula dan pada ketika itu beliau telah terjumpa dengan W.C Cowie iaitu seorang pedagang Scotland yang membuat lawatan ke Hong Kong untuk menguruskan penjualan barang-barang mutiara dan rotan yang diperolehinya melalui sistem tukar barang di Borneo Utara. Walaupun Cowie tidak mengetahui tentang kewujudan konsesi tersebut, namun konsesi Borneo itu telah berjaya menarik perhatian seorang penduduk Hong Kong yang mempunyai reputasi yang sangat baik iaitu Gustavus Baron De Overbeck (Graham Irwin, 1986: 249; H.G Keith, 1980: 124-125). 


\section{PERJANJIAN KESULTANAN BRUNEI DENGAN OVERBECK 1877}

Perlu difahami bahawa Keluasan tanah jajahan Kesultanan Brunei di bahagian Pantai Barat Borneo Utara adalah dari Tanjung Nosong ke wilayah Pandasan. Kawasan-kawasan tersebut kebanyakannya didiami oleh Masyarakat Melayu Brunei, Kedayan, Bisaya, Dusun, Murut, Bajau dan Iranun. Kegagalan Joseph Torrey untuk membangunkan Kimanis tidak melenyapkan usahanya untuk mencari penyewa konsesi baharu di Hong Kong. Dalam usaha Joseph Torrey mencari pembeli baharu yang berminat untuk meneruskan pajakannya di Borneo Utara, seorang konsul AustriaHungry, iaitu Gustavus Baron De Overbeck telah menunjukkan minat untuk mengambil alih wilayah pajakan yang dimiliki oleh Kesultanan Brunei tersebut. Akhirnya, Joseph Torrey berjaya menjualkan haknya itu kepada konsul Austria-Hungry di Hong Kong, iaitu Gustavus Baron De Overbeck. Overbeck bersama-sama dengan Joseph Torrey telah menemui Sultan Brunei untuk mendapatkan persetujuan baginda tentang hak-hak pemilikan yang telah dibeli oleh Overbeck (CO 874/29).

Pada awalnya, Sultan Brunei tidak bersetuju dengan penyerahan ini kerana Sultan Brunei dan Pengiran Temenggung belum dibayar sebarang bentuk pembayaran daripada Joseph Torrey. Sultan Brunei kemudiannya telah dinasihatkan oleh Gabenor British di Labuan iaitu James Brooke dan Setiausaha Gabenor Hugh Low supaya tidak memperkenankan penjualan pajakan tersebut melainkan baginda memeterai perjanjian pajakan baharu dengan Overbeck tanpa melibatkan Torrey. Hal ini bagi mengelakkan daripada berlaku pertindihan perjanjian dan konflik sepertimana yang berlaku ke atas Charles Lee Moses dan Josseph Torrey. Di sebalik tindakan British tersebut, mereka sebenarnya berusaha untuk menyingkirkan Torrey dan menghalang kuasa Amerika daripada terus menguasai Borneo Utara. Pihak kerajaan Amerika sebenarnya menyedari akan perancangan tersebut lantas menghantar kapal perangnya ke Kimanis sebagai amaran kepada Sultan Brunei. Hasil daripada perbincangan Sultan Brunei dengan Gustavus Baron Von de Overbeck di Istana Brunei, maka pada 29 Disember 1877 baginda dan Pengiran Temenggung telah bersetuju untuk menyerahkan wilayah mereka dengan cara memperbaharui semula perjanjian yang dimeterai pada tahun 1865 di antara Charles Lee Moses dan Joseph Torrey 
(Graham Irwin, 1986: 249; H.G Keith, 1980: 124-125). Berdasarkan kepada isi kandungan perjanjian baharu ini, Sultan Brunei dan Pengiran Temenggung telah bersetuju untuk menyerahkan semua wilayah, sungai daratan dan daerah yang terletak di kawasan Teluk Kimanis di Pantai Barat laut Borneo dengan Sungai Sibuku di timur kepada Gustavus Baron de Overbeck. Walau bagaimanapun, selepas Overbeck memperolehi konsesi tersebut, beliau berhasrat untuk menjual pajakan itu kepada saudagarsaudagar Austria yang lain tetapi tidak berjaya. Akhirnya, beliau telah memujuk anak bekas majikannya, iaitu Alfred Dent untuk menjadi rakan kongsinya dan bekerjasama dalam membantu membekalkan kewangan yang diperlukannya di Borneo Utara. Alfred Dent telah bersetuju memberikan wang pendahuluan kepada Overbeck dan mengarahkan Overbeck melaksanakan rancangannya di Borneo (CO 874/29; CO 874/54).

Terdapat beberapa syarat yang perlu dipenuhi di dalam perjanjian tersebut, iaitu pertama, Baron Von Overbeck dan Alfred Dent perlu membayar kepada Sultan Abdul Momin untuk tiga wilayah Tulin yang dimiliki oleh baginda, iaitu Teluk Gaya dan Teluk Sepanggar, Sungai Sulaman sehingga ke Sungai Paitan serta dari Sungai Paitan ke Sungai Sibuku dengan bayaran sebanyak sebanyak \$12000 setahun. Kedua, Baron Von Overbeck dan Alfred Dent juga perlu untuk membayar sebanyak $\$ 3000$ setahun kepada Pengiran Temenggung untuk dua wilayah tulinnya, iaitu Kimanis dan Benoni. Di bawah perjanjian baharu ini juga kedua-dua belah pihak telah bersetuju untuk melakukan pembayaran setiap tahun kepada Sultan Brunei dan Pengiran Temenggung. Seandainya pembayaran ini tidak lakukan dalam tempoh tiga tahun maka Sultan Brunei dan Pengiran Temenggung berhak untuk mengambil semula wilayah berkenaan (CO 874/54).

Kejayaan penyerahan wilayah Pantai Barat utara Borneo oleh Joseph Torrey kepada Baron Von Overbeck dan Alfred Dent ini telah menyebabkan tertubuhnya British North Borneo Provisional Association Limited (BNBL) pada tahun 1881. Sebelum tertubuhnya BNBL, Baron Von Overbeck telahpun dianugerahkan pengiktirafan oleh Sultan Abdul Momin sebagai Maharaja utara Borneo dan Raja Gaya serta Sandakan. Di bawah terma ini, Overbeck dan Alfred Dent mempunyai kuasa untuk menentukan hidup mati penduduk peribumi di kawasan berkenaan. Hal ini kerana beliau mempunyai 
kuasa pemilikan penuh ke atas semua hasil pertanian, ternakan, galian, hak membuat undang-undang, membuat syiling, menubuhkan tentera darat dan laut serta mengenakan cukai kastam. Secara asasnya, isi kandungan dokumen pengiktirafan yang diberikan oleh Sultan Brunei kepada Baron Von Overbeck sebagai Maharaja utara Borneo dan Raja Gaya serta Sandakan ini juga sama sepertimana pengiktirafan baginda kepada Joseph Torrey Sebagai Raja Ambong dan Marudu (CO 874/5; CO 874/32; CO 874/54).

Penglibatan Pengiran Temenggung di dalam urus niaga ini kerana permasalahan pemilikan dan pembahagian tanah yang rumit di Brunei akibat daripada kewujudan sistem Sungai Kerajaan, Kuripan dan Tulin. Oleh kerana Pengiran Temenggung mempunyai hak ke atas sebahagian daripada daerah yang bersempadan dengan Teluk Kimanis, maka Pengiran Temenggung turut menerima dan menikmati ufti yang ditawarkan oleh Baron Von Overbeck. Apa yang menarik mengenai peristiwa penyerahan wilayah ini ialah Baron von Overbeck sebenarnya memperolehi kuasa yang lebih besar berbanding dengan kuasa-kuasa lain yang menjajah Borneo. Hal ini kerana Sultan Brunei telah memberikan kuasa mutlak kepada Overbeck bagi menubuhkan sebuah wilayah bebas yang tidak lagi terikat dengan Kesultanan Brunei (CO 874/32; CO 874/54).

Hakikatnya, tindakan Sultan Abdul Momin menyerahkan wilayahnya di utara Borneo kepada Overbeck telah menyebabkan empayar Kesultanan Brunei semakin mengecil. Biarpun tindakan Sultan Brunei ini adalah untuk menghalang kemaraan kuasa Barat ke empayarnya, namun, baginda tidak dapat menyelesaikan masalah kehilangan wilayah yang berterusan kesan daripada tindakan para pembesarnya menyerahkan wilayah Tulin tanpa pengetahuan baginda. Saiz Brunei yang semakin kecil secara tidak langsung mempengaruhi kemerosotan sumber pendapatan Brunei dari segi kutipan cukai dan kegiatan perdagangan. Oleh hal yang demikian, bagi menampung pendapatan yang makin berkurangan, kerajaan Brunei terpaksa mengenakan cukai yang tinggi ke atas penduduk yang masih berada di bawah naungannya. Tindakan Sultan Brunei melakukan penyerahan wilayah di utara Borneo kepada Overbeck dan Alfred Dent kerana Sultan beranggapan bahawa wilayah tersebut tidak berharga kepada baginda memandangkan pembayaran cukai dalam kalangan penduduk tempatan jarang dilakukan. 
Keadaan tersebut telah menyebabkan baginda memajakkan wilayah tersebut kepada pihak Barat dengan bayaran sebanyak \$9,500 setahun (Ian Black, 1983: 142; Graham Irwin, 1986: 251).

Pemajakan wilayah di utara Borneo ini juga dilakukan kerana Sultan Abdul Momin murka terhadap kerajaan British kerana gagal memberi perlindungan sepertimana yang diharapkan oleh baginda. Kemurkaan ini tercetus apabila kerajaan British tidak mengambil sebarang tindakan untuk menghalang Brooke daripada meluaskan kekuasaannya di Sarawak. Keadaan ini telah menyebabkan baginda memberikan perhatian kepada Konsul Amerika dan seterusnya cuba menyelesaikan masalah kewangan yang dialami oleh empayarnya sehingga membawa kepada pemajakan wilayah di utara Borneo kepada Charles Lee Moses (Awang Othman bin Haji Mat Don, 2010: 95; Graham Saunders, 1994: 84). Dalam hal ini, Kesultanan Brunei menghadapi masalah kewangan bukan sahaja berpunca daripada masalah pembayaran cukai dalam kalangan penduduk tetapi juga ketidaktelusan pembayaran para penyewa syarikat-syarikat pelabur yang menduduki wilayah Kesultanan Brunei (H.G Keith, 1980: 18). Penyerahan ini mudah berlaku kerana wujud ketidak adilan terhadap Brunei. Buktinya, Pejabat Luar Negeri Britain dan Pejabat Tanah Jajahan Britain bersikap memihak kepada Syarikat-Syarikat asing terutamanya berkaitan dengan hal-ehwal pemajakan dan penyerahan wilayah kekuasaan Brunei sama ada secara sukarela, paksaan ataupun rampasan. Hakikatnya, Pejabat Tanah Jajahan Britain sebenarnya memahami dan mengetahui tindakan yang telah mengeksploitasi wilayah Brunei melalui pemajakan dan kelompangan perjanjian yang ditandatangani tetapi mereka seolah-olah membiarkan sahaja keadaan tersebut berterusan terjadi. Pihak kolonial tidak pernah bersikap adil terhadap pemerintah peribumi (Awang Othman bin Haji Mat Don, 2010: 100-101).

Selain itu, keputusan Sultan Brunei memajakkan sungai-sungai tersebut kepada Overbeck dan Alfred Dent serta seterusnya melantik mereka sebagai pemerintah di kawasan berkenaan adalah sebagai alternatif kepada kehilangan pengaruh baginda ke atas Sungai Tulin ${ }^{3}$ yang terletak di timur laut Borneo. Selepas berlaku pemajakan tersebut, Sultan Brunei berharap baginda akan memperolehi pulangan ekonomi dari Sungai Tulin yang sudah terlepas ke tangan Sulu. Tindakan Sultan dan Pengiran Temenggung memajakkan 
sungai-sungai di timur laut Borneo itu menunjukkan bahawa mereka masih menganggap sungai-sungai tersebut sebagai hak mereka walaupun pada hakikatnya wilayah tersebut sudah lama diterajui oleh pengaruh Kesultanan Sulu (Abdul Karim Bin Haji Abdul Rahman, 2014: 140-141).

Di samping itu, Sultan dan pemilik-pemilik Sungai Tulin juga beranggapan bahawa adalah lebih menguntungkan jika Sungai Tulin yang banyak menimbulkan masalah dipajakkan kepada kuasa barat daripada terus berada di bawah pentadbiran mereka. Anggapan sedemikian pernah disuarakan oleh Pengiran Temenggung Anak Hashim kepada para pengikutnya tentang hasrat beliau untuk memajakkan Sungai Tulin kepada Overbeck dan Alfred Dent dengan menawarkan harga yang tinggi. Pendirian ini digunakan bagi sungai-sungai yang menimbulkan masalah dalam pengutipan cukai, namun implikasinya semakin ketara apabila semakin ramai pemilik Sungai Tulin memilih jalan mudah untuk memajakkan Sungai Tulin mereka kepada kuasa Barat berbanding cuba menyelesaikan masalah yang timbul di sungai tersebut. Tindakan ini dilakukan dengan harapan dapat menampung keperluan ekonomi mereka berbanding mendapatkan sendiri melalui kutipan cukai tahunan yang jarang dibayar oleh penduduk (Tarling, N, 1971: 271). Keadaan ini secara tidak langsung telah menyebabkan ramai pemilik Sungai Tulin memajakkan Sungai Tulin masing-masing tanpa menyedari implikasinya terhadap empayar Brunei.

Pada peringkat awal pemajakan Sungai Tulin dan Sungai Kuripan ${ }^{4}$ di Borneo Utara, berlaku atas nama persendirian, iaitu antara Sultan, Pengiran Temenggung Anak Hashim dengan Overbeck dan Alfred Dent. Selepas itu, pihak British bertindak campurtangan di dalam menentukan nasib wilayah-wilayah Brunei yang dipajakkan kepada mereka. Hal ini terbukti apabila pegawai-pegawai British di Pejabat Luar British telah terlibat dalam usaha Alfred Dent membeli kesemua saham Overbeck di Borneo Utara dan membantunya mendapatkan sokongan untuk menubuhkan sebuah syarikat berpiagam (Abdul Karim Bin Haji Abdul Rahman, 2014: 144).

Perlu diperjelaskan bahawa biarpun Sultan menerima sejumlah wang yang banyak hasil daripada pemajakan sungai-sungai tersebut, tetapi perubahan dasar kerajaan British telah membawa implikasi yang besar 
terhadap keselamatan dan keutuhan empayar Brunei. Di sebalik usaha baginda untuk mempertahankan ekonomi dan kuasa politik empayar Brunei, baginda terpaksa juga menyerahkan Sungai Tulin yang tidak mampu baginda kawal. Pemajakan ini kadang-kala menimbulkan masalah apabila wujudnya tentangan daripada ketua-ketua kaum yang tinggal di tempat berkenaan kerana mereka menganggap bahawa Sultan telah melepaskan sungai tersebut kepada mereka. Keadaan ini berlaku disebabkan oleh kebebasan yang mereka nikmati ekoran daripada penurunan kuasa Sultan Brunei di wilayah jajahannya (Awang Othman bin Haji Mat Don, 2010: 147).

\section{PERJANJIAN KESULTANAN SULU DENGAN OVERBECK 1878}

Terdapat dua pandangan yang diutarakan oleh para sarjana mengenai bentuk perjanjian yang dimeterai antara Kesultanan Sulu dengan Overbeck, iaitu sama ada perjanjian tersebut merupakan pajakan yang berbentuk kekal atau selamanya dalam bentuk penyerahan hak dan pemilikan selamanya (cession) dan pandangan kedua adalah berbentuk sewaan bagi tempoh masa tertentu sahaja (lease). Berdasarkan penulisan K.G Tregonning, bentuk perjanjian yang dimeterai adalah pemajakan kekal kerana dalam perjanjian tersebut dituliskan Supreme and Independent, yang membawa maksud pajakan adalah secara berkekalan dan untuk selama-lamanya (K.G Tregonning, 2007: 19). Berdasarkan kepada isi kandungan perjanjian penyerahan Sulu kepada pihak BNBC yang dimeterai pada 22 Januari 1878 menjelaskan bahawa perjanjian tersebut adalah berbentuk kekal atau selama-lamanya (CO 874/54). Selepas tahun 1881 kerajaan British telah mengambilalih tanggungjawab daripada BNBC. Namun, di dalam pembentangan belanjawan British, mereka menggunakan terma "Cession Money" yang bermaksud serahan selama-lamanya (Security Perpetuity) yang perlu dibayar kepada Kesultanan Sulu. Sewaktu persempadanan baharu dilakukan pada tahun 1915, berlaku perubahan dari segi persempadanan yang memperlihatkan Sungai Sibuku berada di bawah kekuasaan Belanda (Mat Zin Mat Kib, 2017: 262-264). Terdapat spekulasi yang menyatakan bahawa sebenarnya perjanjian 1877 dan 1878 telah lama terbatal berikutan perubahan garis persempadanan tersebut (Nik Anuar Nik Mahmud, 2001: 313-314; Hamdan Aziz dan Syahrin Said, 2016: 290). 
Rasionalnya, apabila persempadanan baharu antara Britain dengan Belanda telah dimeterai, maka perjanjian 1877 dan 1878 dianggap terbatal kerana lokasi yang dinyatakan tidak lagi sama sepertimana yang termaktub di dalam perjanjian awal. Biarpun secara asasnya, Sungai Pandasan masih terletak di Pantai Barat utara Borneo, namun Sungai Sibuku sudah berada di dalam kawasan Balikpapan, di Kalimantan Indonesia. Ketika perjanjian persempadanan dilaksanakan, Sepanyol selaku pemerintah Filipina tidak pernah membuat sebarang bantahan malahan sepanjang tempoh 1851 sehinggalah tahun 1881 tidak wujud sebarang tuntutan dari Sepanyol terhadap British berkaitan dengan wilayah Kesultanan Sulu di Pantai Timur Utara Borneo (Hamdan Aziz \& Syahrin Said, 2016: 287). Namun begitu, Sungai Pandasan masih lagi berada di bawah pengaruh BNBC iaitu di kawasan Pantai Barat utara Borneo. Oleh itu, Kesultanan Sulu tidak boleh memiliki sebahagian daripada utara Borneo hanya kerana berdasarkan Sungai Pandasan. Hal ini demikian kerana masih terdapat sungai-sungai yang berada di bawah kekuasaan Brunei seperti Sungai Pengalat, Tempasuk, Putatan, Papar, Klias, Kawang, Padas Damit, Inanam, Mengkabong, Manggatal, Api-Api, Sembulan, Nafas Tembalang, Kinarut dan Membakut. Selain itu, berdasarkan isi kandungan Perjanjian Protokol pada 7 Mac 1885 yang dimeterai di antara Great Britain, Jerman dan Sepanyol di Madrid, tiada satu kuasa kolonial di Filipina mengkategorikan utara Borneo sebagai wilayahnya. Dalam perjanjian ini juga persempadanan Filipina yang disahkan ialah sembilan batu dari Pantai Timur utara Borneo berlandaskan kepada peraturan antarabangsa. Hakikatnya, geran pajakan yang diserahkan oleh Kesultanan Sulu kepada BNBC sebenarnya diatasi oleh Perjanjian Protokol ekoran daripada wujudnya Artikel III yang menyatakan pelepasan tuntutan terhadap kedaulatan wilayah utara Borneo (CO 874/54; FO 71/18).

\section{Artikel III}

The Spanish Government renounces, as far as regards the British Government, all claims of Sovereignty over the territories of continent of Borneo, which belong, or which have belonged in the past to the Sultan Sulu (Jolo), and which comprised the neighbouring islands of Balambangan, Banguey and Malawali, as well as all the comprised within a zone of three maritime leagues from the coast and which from part of the territories administrated by the company styled the "British North Borneo Company (FO 71/18). 
Merujuk kepada Artikel III, kerajaan Sepanyol telah melepaskan semua tuntutan ke atas kedaulatan wilayah-wilayah di utara Borneo kepada Kerajaan British yang telah dimiliki pada masa lalu oleh Kesultanan Sulu termasuklah pulau-pulau yang ada disekitarnya iaitu Balambangan, Banguey dan Malawali. Perkara ini sekali gus membuktikan status kekuasaan Kesultanan Sulu yang telah hilang dari segi de jure dan de facto. Kenyataan ini juga menyokong bahawa pemerintahan Kesultanan Sulu telah lama berakhir di Kepulauan Borneo dan keadaan ini terus kekal sehinggalah Amerika Syarikat memberikan kemerdekaan kepada Kerajaan Filipina pada 4 Julai 1946 dengan tidak memasukkan wilayah di utara Borneo sebagai sebahagian daripada wilayahnya (Hamdan Aziz dan Syahrin Said, 2016: 287)

Jika diteliti pemeteraian perjanjian 1878 ini bersandarkan kepada perspektif Kesultanan Brunei, baginda tidak pernah memperakui sebarang bentuk penyerahan wilayah Brunei di utara Borneo kepada Kesultanan Sulu. Pengiktirafan British terhadap wilayah Kesultanan Sulu di Pantai Timur hanyalah disebabkan oleh pengaruh Kesultanan Sulu terhadap penduduk di kawasan tersebut memandangkan majoriti penduduknya adalah pengikut setia Kesultanan Sulu, iaitu bersifat de facto. Kebanyakan hujah tuntutan penyerahan Pantai Timur kepada Kesultanan Sulu hanya dilihat dalam tulisan para sarjana Barat yang bersumberkan tradisi Kesultanan Sulu, iaitu Silsilah Sulu abad ke-19 tetapi penyerahan ini tidak diperakui oleh para sarjana Brunei masa kini yang menonjolkan perbezaan yang ketara daripada apa yang dijelaskan oleh para sarjana Barat terdahulu. Perkara ini juga turut banyak diutarakan di dalam kajian-kajian Brunei yang ditulis oleh Mohd Jamil AlSufri. Kenyataan ini turut disokong oleh Abdul Karim Bin Haji Abdul Rahman (2014) yang menyatakan bahawa faktor penyerahan wilayah di utara Borneo oleh Sultan Abdul Momin kepada Overbeck adalah disebabkan oleh hilangnya pengaruh baginda terhadap wilayah Tulin di Pantai Timur. Perlantikan Overbeck sebagai Maharaja utara Borneo dan Raja Gaya serta Sandakan oleh Sultan Brunei merupakan satu langkah untuk melindungi kedaulatan baginda daripada tercemar rentetan hilangnya pengaruh serta kekuasaan baginda di Pantai Timur. Baginda juga beranggapan bahawa dengan pemajakan wilayah tersebut, baginda akan memperolehi lebih banyak keuntungan dengan nilai bayaran tahunan yang tetap berbanding dengan sebelumnya (Nicholas Tarling, 1971: 271; Abdul Karim Bin Haji Abdul Rahman, 2014: 140-141). 
Berdasarkan penulisan Raffles (1982), tidak wujud sebarang penyerahan di antara Kesultanan Brunei dan Kesultanan Sulu terhadap wilayah di Pantai Timur. Hal ini kerana Kesultanan Sulu masih lagi menuntut wilayah Pantai Timur daripada Kesultanan Brunei untuk tempoh yang sangat lama. Perkara ini turut disokong oleh Graham Irwin yang menyatakan bahawa perjanjian yang dimeterai oleh Overbeck dengan Kesultanan Sulu pada tahun 1878 hanyalah disebabkan oleh sokongan ketua-ketua tempatan terhadap kedaulatan Kesultanan Sulu sebagai pemerintah berbanding dengan Kesultanan Brunei (Graham Irwin, 1986: 197). Keadaan ini menunjukkan bahawa Kesultanan Sulu masih lagi menuntut wilayah berkenaan daripada Kesultanan Brunei sehinggalah pihak Barat muncul untuk mengiktiraf kebertuanan Sulu terhadap wilayah di Pantai Timur utara Borneo. Oleh itu, satu-satunya bukti yang menyatakan wujudnya penyerahan wilayah Pantai Timur oleh Sultan Brunei kepada Kesultanan Sulu ini hanyalah bersandarkan kepada sumber Barat yang ditulis oleh Hugh Low dan tidak melihat aspek pensejarahannya melalui politik Brunei (Eko Prayitno Joko, 2015: 14). Biarpun Cesar Adib Majul (2010) dalam kajiannya Muslim in the Philippines menjelaskan bahawa penyerahan wilayah Pantai Timur adalah sah, namun pandangan beliau hanya terbatas kepada aspek persepsinya terhadap sudut fizikal masyarakat Suluk itu sendiri yang bersikap berani serta tidak gentar di medan perang dan amat mustahil untuk mereka melarikan diri. Namun, kenyataan ini disangkal oleh Mohd Jamil Al-Sufri yang menjelaskan bahawa tentera-tentera Suluk kebanyakan bersembunyi di Pulau Keingaran dan mereka tidak membantu Sultan Muhyiddin untuk menentang Sultan Hakkul Mubin di Pulau Chermin (Mohd Jamil Al-Sufri, 1994: 19-20).

Biarpun tidak wujud sebarang penyerahan wilayah di Pantai Timur oleh Sultan Brunei namun, konflik dalaman istana yang berterusan, ancaman daripada James Brooke serta desakan British untuk meminta Sultan Brunei menyerahkan Pulau Labuan dan wilayah Pantai Barat utara Borneo menyebabkan empayar Kesultanan Brunei mula tergugat dan lemah. Hal ini kerana Kesultanan Brunei tidak lagi mampu untuk mempertahankan wilayah jajahannya di Borneo. Keberhasilan pemilikan Kesultanan Sulu terhadap wilayah ini hanya berlaku apabila wujud campurtangan daripada pihak Barat yang telah bertindak mengiktiraf penguasaan Kesultanan Sulu di wilayah tersebut. Dengan pengiktirafan itu, maka pada 22 Januari 1878, 
Sultan Sulu telah memindahkan kedaulatannya bagi semua wilayah yang terletak dari Sungai Sibuku ke Sungai pandasan, Sugut, Bonggaya, Labok, Sandakan, Kinabatangan dan Moming termasuklah pulau-pulau sekitar Teluk Darvel tersebut kepada Overbeck. Sebagai tambahan Sultan Sulu telah melantik Overbeck sebagai pemerintah tertinggi bebas dengan gelaran Datu Bendahara dan Raja Sandakan (CO 874/54).

Perlu diketahui bahawa walaupun wujud perjanjian yang dimeterai antara Overbeck dan Sultan Sulu untuk membenarkan pemindahan hak wilayah kepada pihak Barat, isu pemilikan Pantai Timur ini masih boleh diragui kesahihannya. Hal ini kerana pihak Barat sengaja menggunakan isu bantuan tentera Sulu ke atas Brunei semasa Perang Saudara sebagai alasan untuk mengesahkan dan mengiktiraf ketuanan Sulu secara politikalnya di Pantai Timur. Tujuannya adalah untuk melindungi para pemodal yang berada di bawah naungan British untuk mencari keuntungan dan seterusnya menghalang kuasa asing lain daripada menguasai utara Borneo (Eko Prayitno Joko, 2015: 15; North Borneo Herald 1 Mac 1883). Bersandarkan kepada catatan Raffles, Irwin dan para pengkaji sejarah Brunei masa kini, pemilikan Kesultanan Sulu terhadap wilayah Pantai Timur utara Borneo masih lagi boleh dipersoalkan kesahihannya berikutan wujud banyak percanggahan dan kelompangan maklumat dari segi hujah yang disampaikan oleh sarjana barat terdahulu. Namun begitu, secara realitinya, pihak Barat sebenarnya lebih cenderung untuk menerima kenyataan bahawa wilayah Pantai Timur utara Borneo dimiliki oleh Kesultanan Sulu berbanding dengan Kesultanan Brunei.

Sememangnya, sejak dari awal permeteraian perjanjian 1878 lagi Sepanyol mulai memperlihatkan penentangannya terhadap pemajakan British ke atas wilayah di Pantai Timur. Hal ini kerana Sepanyol menganggap Perjanjian 1851 yang dimeterai di antara Sepanyol dan Sulu adalah penyerahan yang kekal. Situasi ini diperkukuhkan lagi apabila enam bulan selepas termeterainya perjanjian British-Sulu, semua wilayah di bahagian timur Kalimantan Utara telah dipindahkan kepada kuasa Sepanyol untuk diusahakan. Namun bagi pihak Kesultanan Sulu, mereka beranggapan bahawa Perjanjian 1851 hanyalah tertumpu pada Kepulauan Sulu dan bukannya kawasan jajahan Sulu di Pantai Timur utara Borneo. Ini bermakna 
bahawa wilayah jajahan Sulu di Pantai Timur utara Borneo masih lagi kekal di bawah penguasaan Kesultanan Sulu. Perkara ini dapat dilihat apabila Kesultanan Sulu terpaksa melalui beberapa siri peperangan dengan Sepanyol meskipun Perjanjian 1851 telah ditandatangani antara kedua-dua belah pihak. Peperangan ini juga turut berlanjutan sehinggalah datangnya kuasa Amerika Syarikat mengalahkan Sepanyol di Filipina (Graham Irwin, 1986: 253; Eko Prayitno Joko, 2015: 20). Konflik di antara British dan Sepanyol mencapai kemuncaknya apabila Perjanjian Protokol Madrid terpaksa ditandatangani antara British, Jerman dan Sepanyol pada tahun 1885 untuk menggariskan wilayah kekuasaan bagi setiap negara. Di bawah perjanjian ini Sepanyol terpaksa melepaskan semua tuntutan terhadap wilayah di utara Borneo manakala Jerman telah mengiktiraf kedaulatan Sepanyol ke atas Kepulauan Sulu termasuklah Cagayan dan Balabak (Najeeb M. Saleeby, 2013: 371).

Selain daripada Sepanyol, Belanda juga turut menentang penyerahan wilayah Sulu ini kerana beranggapan bahawa wilayah Pantai Timur adalah sebahagian daripada kekuasaannya. Tindakan Belanda ini adalah bersandarkan kepada perjanjian yang telah dimeterai antara Sultan Bulungan, iaitu Sultan Kaharuddin pada tahun 1850 yang memperlihatkan bahawa kedaulatan Sultan Bolongan terletak dalam pengaruh Belanda. Permasalahan di antara British dengan Belanda ini mula berlaku apabila wilayah di bahagian selatan yang bersempadan dengan Teluk Darvel dan semua pulau milik British bertindan dengan wilayah sempadan yang dimiliki oleh Belanda. Persengketaan ini telah menyebabkan Belanda menghantar pasukan kapal meriamnya pada tahun 1879 ke Batu Tinagat Tawau sebagai tanda protes untuk mengekang pengaruh British di wilayah Pantai Timur (Eko Prayitno Joko, 2015: 21-23).

Pertikaian ini mencapai kemucaknya apabila Dent memperoleh Piagam Diraja British untuk membangunkan Borneo Utara pada 1 November 1881. Pemberian piagam ini telah menyebabkan wujudnya desakan daripada pihak Pejabat Luar British untuk mempertahankan wilayah Borneo Utara dari pencerobohan Belanda (J. De. V. Allen, A. J Stockwell, 1981: 450). Dalam keadaan tersebut, pihak British telah bertindak mengiktiraf perjanjian 1877 dan 1878 dan memberikan jaminan bahawa BNBC tidak akan menuntut sebarang wilayah kecuali yang telah dipajakan oleh Kesultanan 
Brunei dan Kesultanan Sulu. Konflik ini akhirnya berjaya diselesaikan apabila kedua-dua belah pihak bersetuju menubuhkan suruhanjaya bersama untuk mengkaji semula persempadananan wilayah di antara British dan juga Belanda di Pantai Timur Borneo Utara pada tahun 1891 (Eko Prayitno Joko, 2015: 23). Perjanjian ini kemudiannya diguna pakai oleh kedua-kedua belah pihak sehinggalah kini sebagai dasar dan warisan daripada pihak kolonial Belanda dan British untuk menetapkan batas persempadanan di antara kedua-dua negara. Secara teknikalnya, penyelesaian masalah yang dilakukan oleh Kesultanan Brunei dan Kesultanan Sulu ini menggambarkan kebergantungan mereka terhadap kuasa Barat untuk memperolehi perlindungan dan keamanan di dalam wilayah masing-masing. Tindakan kedua-dua kesultanan ini juga memperlihatkan kesukaran mereka untuk mempertahankan sistem monarki masing-masing supaya terus kekal dan tidak musnah akibat ancaman kuasa luar.

\section{PERBANDINGAN PERJANJIAN PENYERAHAN WILAYAH KESULTANAN BRUNEI DAN KESULTANAN SULU 1877 DAN 1878}

Proses perjanjian penyerahan wilayah Kesultanan Brunei dan Kesultanan Sulu sangat berbeza. Perbezaan ini dapat dilihat dari segi bentuk penyerahan yang dimeterai antara kedua-dua belah pihak sama ada berbentuk pajakan ataupun penyerahan kekal. Perlu diperjelaskan di sini bahawa penyerahan wilayah oleh Kesultanan Brunei dan Pengiran Temenggung adalah bersifat de jure kerana penyerahan wilayah tersebut telah dipersetujui secara perjanjian dan diiktiraf oleh negara lain. Lazimnya, penyerahan wilayah ini berlaku disebabkan oleh kewujudan pelbagai konflik di dalam wilayah masing-masing yang akhirnya mendorong kepada berlakunya penyerahan wilayah kepada kuasa Barat.

Perlu diketahui bahawa perjanjian penyerahan wilayah Pantai Barat utara Borneo oleh Kesultanan Brunei dan Pengiran Temenggung bukanlah berlaku sekaligus tetapi melibatkan beberapa fasa dan peringkat. Pada awalnya, status penyerahan wilayah Kesultanan Brunei ini berbentuk pajakan ekoran daripada masalah kewangan yang dialami oleh empayar Kesultanan Brunei. Fasa perjanjian penyerahan wilayah Kesultanan 
Brunei ini bermula pada tahun 1877 dan dilakukan melalui tujuh peringkat perjanjian iaitu peringkat pertama, perjanjian penyerahan Pulau Labuan oleh Sultan Omar Ali Saifuddin II kepada kerajaan British pada 17 Disember 1846. Peringkat Kedua, perjanjian penyerahan oleh Sultan Abdul Momin dan Pengiran Temenggung Maulana Hashim pada tahun 1877 kepada Baron Von Overbeck dan Alfred Dent. Sultan Abdul Momin telah menyerahkan wilayah Likas, Papar, Inanam, Pulau Gaya, Tanjung Lutut, Menggatal, Tanjung Sepanggar, Pulau Sepanggar, Tuaran, Sulaman, Ambong, Abai, Pulau Usukan, Tempasuk, Pulau Matanani dan Pandasan. Pengiran Temenggung pula menyerahkan Kimanis, Kokah, Bambangan, Benoni, Pulau Dinawan dan Pulau Tiga. Peringkat Ketiga ialah perjanjian penyerahan oleh Sultan Abdul Momin, Pengiran Bendahara Anak Muhammad dan Pengiran Digadong Anak Muhammad Hassan terhadap kawasan Tanjung Nosong, Kuala Penyu dan Bongawan serta penyerahan oleh Pengiran Muda Damit terhadap Putatan pada tahun 1884 kepada pihak BNBC. Peringkat Keempat, perjanjian penyerahan oleh Syarif Jair Bin Maulana Syarif Abdul Rahman terhadap sungai Tulinnya iaitu Kawang kepada pihak BNBC pada tahun 1885. Peringkat kelima, berlaku pada tahun 1897 apabila Pengiran Jalaluddin Ibni Pengiran Abdul Rauf menyerahkan Kinarut. Peringkat Keenam, perjanjian penyerahan dilakukan oleh Sultan Hashim kepada pihak BNBC melibatkan kawasan Membakut, Kuala Lama, Api-Api, Inanam, Menggatal dan Mengkabong pada tahun 1898. Peringkat Ketujuh, perjanjian penyerahan dilakukan oleh Pengiran Jalaludin Ibni Pengiran Abdul Rauf ke atas wilayah Tulinnya iaitu Sembulan, Nafas Tambalang, Dumpil dan Kabatuan pada tahun 1901 (CO 874/54).

Kebanyakan wilayah yang diserahkan kepada pihak British adalah tanah jenis Tulin yang dimiliki oleh para pembesar. Oleh kerana itu, proses penyerahan wilayah di utara Borneo tidak boleh berlaku secara serentak memandangkan Sultan tidak berhak untuk mencampuri hal-ehwal tanah jenis Tulin milik pembesar. Sultan Brunei juga tidak dapat menahan atau menghalang para pembesarnya untuk menjualkan hak Tulinnya kepada pihak British. Keadaan inilah yang menyebabkan empayar Kesultanan Brunei mengalami kemerosotan yang berpanjangan kerana Sultan Brunei tidak mampu untuk mengawal para pembesarnya daripada terus menyerahkan hak Tulin mereka kepada pihak British. Walau bagaimanapun, 
keadaan ini berbeza sekali dengan Kesultanan Sulu kerana Sultan Sulu tidak memerlukan persetujuan daripada para pembesarnya yang terdiri dalam kalangan golongan Datu untuk menyerahkan wilayahnya di Pantai Timur kerana wilayah tersebut adalah tanah naungan Kesultanan Sulu. Oleh yang demikian itu, maka penyerahan yang dilakukan oleh Kesultanan Sulu adalah bersifat menyeluruh dan bukannya berperingkat-peringkat sepertimana yang berlaku di dalam pemerintahan Kesultanan Brunei.

Selain itu, perebutan takhta yang berterusan di dalam pemerintahan Kesultanan Brunei dan kegagalan pemilik Tulin untuk mengawal dan mengawasi sepenuhnya wilayah milik peribadi masing-masing menyebabkan berlakunya penentangan secara terbuka dalam kalangan masyarakatnya sehingga mendesak golongan pembesar menyerahkan wilayah Tulinnya kepada pihak BNBC. Keadaan ini berbeza sekali dengan permasalahan yang dialami oleh Kesultanan Sulu kerana penyerahan yang dilakukan oleh Kesultanan Sulu berkait rapat dengan konflik politik di antara Kesultanan Sulu dan Sepanyol. Peperangan yang berterusan di antara kedua-dua belah pihak telah menyebabkan Sultan Sulu bukan sahaja bimbang wilayahnya di Pantai Timur utara Borneo akan diambilalih oleh Sepanyol malah baginda juga memerlukan sumber kewangan yang mencukupi untuk menghadapi peperangan dengan Sepanyol lantas mengambil kesempatan tersebut untuk menyerahkan wilayahnya kepada Overbeck dan Alfred Dent (CO 874/54).

Seterusnya, perkara-perkara tambahan yang berkaitan dengan perbezaan kandungan perjanjian Kesultanan Brunei dan Kesultanan Sulu ini ialah dari segi ketekalan terma perjanjian. Didapati bahawa di dalam perjanjian Brunei dengan Overbeck terdapat terma dan syarat baharu telah dilakukan di dalam perjanjian yang melibatkan perjanjian Kesultanan Brunei dengan Overbeck. Perubahan ini dilakukan bukan sahaja untuk melindungi empayar Brunei dari diancam oleh kuasa luar akan tetapi untuk mengelakkan kuasa luar mengambilalih wilayah-wilayah jajahan Brunei di Borneo. Manakala bagi perjanjian Sulu pula, tidak ada sebarang pindaan dilakukan di dalam perjanjian tersebut melainkan wujudnya beberapa spekulasi yang menyatakan tentang pembatalan perjanjian 1877 dan 1878 ekoran daripada berlakunya perubahan persempadanan sungai-sungai rentetan daripada perjanjian Britain dan Belanda pada tahun 1915 (Mat Zin Mat Kib, 2017: 
262-264; Hamdan Aziz dan Syahrin Said, 2016: 287). Walau bagaimanapun dalam konteks ini, dapat dilihat bahawa kesemua perjanjian yang dilakukan oleh kedua-dua Kesultanan ini mencerminkan kelemahan mereka untuk mengawal politik pentadbiran di wilayah jajahan masing-masing. Perkara ini sememangnya disedari oleh pihak Overbeck serta Alfred Dent dan mereka menggunakan peluang tersebut untuk mengawal kedua-dua Kesultanan berkenaan supaya mengikuti kesemua terma perjanjian Barat yang telah ditetapkan oleh kerajaan British biarpun secara literalnya perjanjian tersebut dilakukan atas persetujuan bersama.

Di sebalik perbezaan tentang bentuk perjanjian penyerahan wilayah jajahan masing-masing, terdapat juga persamaan kaedah perjanjian yang digunapakai oleh pihak $\mathrm{BNBC}$, iaitu dari segi penggunaan terma Barat berbanding dengan terma Melayu untuk semua perjanjian yang dimeterai dengan Kesultanan Brunei dan Kesultanan Sulu. Hal ini dapat dibuktikan apabila kesemua terma perjanjian yang dimeterai oleh Kesultanan Brunei dan Kesultanan Sulu bukan sahaja mengikuti sepenuhnya terma Barat malah banyak menggunakan pengistilahan bahasa Inggeris yang mempunyai maksud dan kefahaman yang berbeza dengan tradisi Melayu. Keadaan ini mula menimbulkan masalah apabila golongan sejarawan mulai mengkaji tentang isi kandungan perjanjian dan menterjemahkannya ke dalam bahasa Melayu mengikut kefahaman serta perspektif perundangan semasa. Secara teknikalnya, di dalam kes perjanjian Sulu dengan BNBC, versi terjemahan kandungan perjanjian tersebut seharusnya tidak menimbulkan masalah yang boleh memperlihatkan makna yang bertentangan dengan versi bahasa Inggeris tetapi perkara ini menjadi rumit dan menimbulkan implikasi yang besar terhadap masyarakat apabila wujudnya tafsiran yang pelbagai terhadap perjanjian tersebut. Sentimen ini juga bukanlah sesuatu yang boleh dianggap terpencil kerana isu ini mendapat sambutan yang meluas daripada golongan sejarawan yang mengutarakan nada dan pandangan yang berbeza sehingga menimbulkan persepsi yang pelbagai (Lela Garner Noble, 1977: 21-25).

Selain itu, persamaan isi kandungan perjanjian Brunei dan Sulu ini juga boleh dilihat dari segi pengaplikasian perjanjian utama yang merujuk kepada penyerahan kedaulatan wilayah di utara Borneo kepada kerajaan BNBC. Perkara yang terpenting dalam perjanjian ini ialah terma penyerahan 
wilayah yang dinaungi oleh kedua-dua Kesultanan ini dilakukan secara legal kepada BNBC dengan penambahan beberapa perkara berikut iaitu;

i. Kesultanan Brunei dan Kesultanan Sulu perlu memberikan apa-apa bantuan jika diperlukan di samping bekerjasama untuk melindungi kepentingan perdagangan BNBC di utara Borneo. Di bawah terma yang sama juga BNBL berjanji untuk sedaya upaya melindungi wilayah Kesultanan Brunei dan Sulu selagimana Kesultanan Brunei dan Sulu juga turut bekerjasama melindungi wilayah-wilayah yang berada di bawah pengaruh BNBC.

ii. Kesultanan Brunei dan Sulu tidak boleh menjalinkan hubungan luar dengan kuasa lain tanpa kebenaran Ratu England.

iii. Semua wilayah-wilayah yang telah dipajakan kepada BNBC tidak boleh dipindah milik kepada kuasa lain tanpa kebenaran Ratu England.

Terma perjanjian yang dibincangkan di atas merujuk kepada perjanjian bertulis di antara British dan Brunei pada 17 Ogos 1878 yang telah dipinda daripada klausa VIII dalam perjanjian 1476 yang telah menggariskan provisi-provisi penting untuk dipenuhi di dalam perjanjian awal di antara Kesultanan Brunei dan Kesultanan Sulu. Justeru itu, kesemua saranan yang terdapat di dalam perjanjian awal telah dimasukkan ke dalam Piagam Diraja dan menjadi rang undang-undang yang perlu dipatuhi oleh pihak BNBC (CO 874/32; FO 71/1; FO 93/46/25).

Di samping itu, Kesultanan Brunei dengan Kesultanan Sulu juga mempunyai persamaan di dalam proses permeteraian perjanjian penyerahan wilayah kepada pihak BNBC. Hal ini dapat dilihat apabila Kesultanan Brunei dan Sulu ini mengalami permasalahan kewangan yang meruncing sehingga melumpuhkan sumber pendapatan dan ekonomi di empayar masing-masing. Keadaan ini secara tidak langsung telah mengheret kedua-dua Kesultanan ini untuk menyerahkan wilayah mereka kepada pihak BNBC. Kesempatan ini juga telah digunakan sepenuhnya oleh pihak BNBC untuk memastikan wilayah utara Borneo menjadi miliknya dan seterusnya dapat menghalang kuasa asing lain daripada memilikinya. Biarpun secara dasarnya Kesultanan Brunei tidak pernah mengiktiraf pengambilalihan wilayah Pantai Timur 
oleh Kesultanan Sulu namun, pihak Kesultanan Sulu tetap menganggap bahawasanya wilayah tersebut adalah miliknya. Disebabkan kepercayaan itu, maka Kesultanan Sulu telah menandatangani banyak perjanjian dengan kuasa Barat khususnya Sepanyol, Belanda dan British. Bersandarkan kepada perjanjian tersebut maka setiap kuasa Barat ini mengakui bahawa mereka berhak untuk membangunkan wilayah Kesultanan Sulu.

\section{KESIMPULAN}

Perubahan status pemajakan wilayah di utara Borneo bermula apabila Charles Lee Moses memperoleh pajakan daripada Sultan Brunei. Dikesempatan itu, Charles Lee Moses telah bertindak memajakan haknya kepada Joseph Torrey, Thomas Harris dan Wo-Hang dengan meletakkan utara Borneo di bawah naungan ATC yang akhirnya mengalami kemerosotan modal yang berterusan sehingga Joseph Torrey terpaksa memajakan haknya kepada pedagang Austria-Hungry iaitu Baron Von Overbeck dan Alfred Dent. Penyerahan wilayah utara Borneo 1865, 1877 dan 1878 memperlihatkan wujudnya pelbagai pertikaian dan spekulasi berkaitan intipati perjanjian dan status penyerahan sama ada berbentuk pajakan ataupun penyerahan kekal. Di dalam hal ini, meskipun penyerahan wilayah yang dilakukan oleh Kesultanan Brunei dan Pengiran Temenggung kepada Overbeck serta Alfred Dent dilakukan melalui beberapa fasa dan peringkat namun, penyerahan tersebut adalah bersifat kekal. Walau bagaimanapun, situasi ini berbeza dengan perjanjian penyerahan wilayah Sulu yang mempunyai pelbagai pandangan dan persepsi berbeza dalam kalangan sejarawan. Hal ini bukan sahaja disebabkan oleh perubahan persempadanan di dalam perjanjian Britain dan Belanda 1915 tetapi juga wujudnya pelbagai tafsiran terhadap kandungan perjanjian sehingga menimbulkan implikasi besar terhadap kefahaman masyarakat. Di dalam konteks ini, didapati bahawa pihak Overbeck serta Alfred Dent telah berjaya menggunakan kelemahan politik pentadbiran Kesultanan Brunei dan Kesultanan Sulu untuk mengikuti kesemua terma perjanjian Barat yang telah ditetapkan oleh kerajaan Britain walaupun secara literalnya perjanjian tersebut dilakukan atas persetujuan bersama. Hakikatnya, perjanjian penyerahan ini telah mengubah landskap politik pentadbiran Borneo Utara secara menyeluruh kerana melalui perjanjian inilah BNBC berjaya memiliki sebahagian wilayah pantai barat 
dan pantai timur di Borneo Utara. Penyerahan wilayah utara Borneo ini juga merupakan isyarat awal yang mendeskripsikan keinginan BNBC bukan sahaja untuk memiliki keseluruhan sumber ekonomi tetapi juga untuk mengukuhkan kedudukan serta kekuasaan mereka di Borneo Utara.

\section{NOTA}

${ }^{1}$ Perjanjian pajakan kali kedua ini dinamakan sebagai Perjanjian Memorandum I di antara Charles Lee Moses, Thomas Bradley Harris dan Wo Hang. Di dalam penyerahan konsesi tanah tersebut, Charles Lee Moses telah meletakkan syarat kepada Joseph William Torrey, Thomas Bradley Harris dan Wo Hang selaku penyewa kedua konsesi tanah Sultan Brunei dan Pengiran Temenggung, supaya menjalankan perdagangan mengikut kehendak firma American Trading Company of Borneo. Perjanjian Memorandum ke-II pula dimeterai pada 25 Oktober 1865 selepas berlakunya beberapa pindaan di dalam perjanjian Memorandum I. Perjanjian ini adalah untuk tempoh setahun bermula dari 25 Oktober 1865 dan dikenakan tempoh 10 tahun untuk melakukan perubahan. Isi Kandungan Perjanjian Memorandum ke-II ini memperlihatkan Parker \& Co (Joseph William Torrey) dan Harris \& Pond New York telah dilantik sebagai agen Syarikat Perdagangan bagi American Trading Company. Lihat CO 874/4, Memorandum Agreement between Joseph William Torrey, Thomas Bradley Harris, Asing, Apong, Hong Kong, 25 October 1865.

${ }^{2}$ Perjanjian pajakan pada 11 Ogos 1865 melibatkan Charles Lee Moses telah dipinda selepas berlakunya pemindahan konsesi kepada syarikat ATC yang di ketuai oleh Josseph Torrey, Thomas Harris dan Wo Hang. Perjanjian 24 dan 29 November 1865 serta 21 June 1875 telah memberikan pengiktirafan kepada syarikat ATC untuk mentadbir sepenuhnya wilayah jajahan Kesultanan Brunei. Lihat Perjanjian CO 874/2, Sultan's Comission of Torrey as Raja. Lihat juga CO 874/6 Brunei Grant of Banguey Island to Moses. Lihat juga CO 874/13, Temenggung Grant to Torrey.

${ }^{3}$ Pemilikan sungai Tulin atau pesaka merujuk kepada tanah yang dimiliki oleh golongan pembesar (Pengiran) secara persendirian. Hal ini kerana sekiranya pemilik tanah iaitu golongan Pengiran meninggal dunia, maka pemilikan tersebut boleh diserahkan kepada keturunannya yang dikenali sebagai Pesaka. Harta pemilikan jenis ini terdiri dari sungaisungai dan penduduk yang juga dikenali sebagai Sungai Tulin atau Hamba Tulin. Sultan tidak boleh memungut cukai daripada penduduk atau daerah yang termasuk dalam kelompok Tulin. Sultan juga tidak boleh mengurniakan tanah-tanah tersebut kepada sesiapapun tanpa merujuk kepada pemiliknya melainkan tanah-tanah tulin tersebut dimiliki sendiri oleh Sultan. Juga lihat D.S. Ranjit Singh, (1991), op.cit., hlm. 27.

${ }^{4}$ Sungai Kuripan merujuk kepada tanah yang dimiliki oleh wazir menteri. Kuasa pemilikan itu hanya diberikan sewaktu mereka masih hidup dan memegang jawatan tersebut. Sekiranya mereka meninggal dunia maka hak tersebut akan diserahkan semula kepada Sultan sehingga pengganti baru dilantik untuk mengisi jawatan tersebut. Keadaan ini menunjukkan bahawa hak pemilikan tanah jenis Kuripan akan diberikan berdasarkan kepada jawatan dan bukannya warisan kekal. Pendapatan di wilayah Kuripan ini diperoleh melalui hasil pungutan cukai tanah, cukai kepala dan cukai khas perdagangan. Sabihah Osman et.al, op.cit., hlm. 25-27. 


\section{RUJUKAN}

Sumber Pertama (dokumen dan surat khabar)

CO 874/2. (1865). Brunei Grant of North Borneo to Moses (U.S Consul). 11 August.

CO 874/2. (1865). Temenggong of Brunei’s Grant to Moses. 11 August.

CO 874/2. (1865). Sultan's Comission of Torrey as Raja. 24 November.

CO 874/4. (1865). Memorandum Agreement between Joseph William Torrey,

Thomas Bradley Harris, Asing, Apong. Hong Kong. 25 October.

CO 874/5. (1865). Sultan's Commission of Torrey as Raja. 24 November.

CO 874/6. (1865). Brunei Grant of Banguey Island to Moses. 29 November.

CO 874/13. (1875). Temenggung Grant to Torrey. 21 June.

CO 874/29. (1881). Indenture between Joseph Torrey and Alfred Dent. 15 January.

CO 874/32. (1881). Indenture between Alfred Dent and the British North Borneo

Provisional Association. 6 July.

CO 874/54. (1877). Grant by Sultan of Brunei of Territories from Paitan to Sibuku

River. 29 December.

CO 874/54. (1877). Grant by Pengiran Temenggung of Brunei of Provinces of Kimanis dan Benoni. 29 December.

CO 874/54. (1877). Grant by Sultan of Brunei of Territory the Sulaman River to the River of Paitan, 29 December.

CO 874/54. (1878). Grant by Sultan Sulu of Territories and Lands on the Mainland of the Island of Borneo. 22 January.

CO 874/54. (1898). Grant of Menggatal, Mengkabong, Api-api, Sembulan, Napas, Tembalang. 23 March.

CO 874/54. (1877). Commision from Sultan of Brunei Appointing Gustavus Baron

De Overbeck Maharajah of North Borneo, and Raja of Gaya and Sandakan.

29 December.

CO 874/54. (1865). Sultan's Commission of Torrey as Raja, 24 November.

FO 12/33. (1866). Torrey to Thomas Harris Bradley Harris. Hong Kong. 2 May.

FO 71/1. (1761). Dalrymple's First Treaty With Sulu. 28 January.

FO 71/1. (1763). Dalrymple's Second Treaty With Sulu. 19 September.

FO 93/46/25. (1871). Convention between Great Britain and the Netherlands for

Settlement of their mutual relations in the Island of Sumatra. Signed at the

Hague. 2 November.

FO 71/18. (1885). Protocol between Great Britain, Germany and Spain, Signed at Madrid, 7 March.

North Borneo Herald. (1883, 1 March). 


\section{Buku dan Artikel}

Abdul Karim Bin Haji Abdul Rahman. (2014). Meruntuhkan empayar Brunei KMXIX: satu kajian dari sudut ekonomi. Kementerian Kebudayaan. Belia dan Sukan Bandar Seri Begawan: Pusat Sejarah Brunei.

Allen, J. De V., Stockwell, A.J \& Wright L.R (pnyt.). (1981). A collection of treaties and other documents affecting the states of Malaysia 1761-1963. Vol.I. Jil.2. London: Oceana Publications.

Awang Othman Bin Haji Mat Don. (2010). KMXVII-XIX: An analysis of the history of its decline. Jurnal Darussalam. Jil.10. 91.

Cesar Adib Majul. (2010). Muslim in the Philipines. Retrospective Issue 1. Vol. 46. 1-2 . Asian Studies: University of the Philippines Press.

Eko Prayitno Joko. (2015). Isu pemilikan wilayah pantai timur Sabah: satu penelusuran daripada sudut sumber sejarah, Kota Kinabalu: Universiti Malaysia Sabah.

Hamdan Aziz dan Syahrin Said. (2016). Tuntutan Kesultanan Sulu terhadap Sabah: sorotan dari perspektif sejarah dan perundangan. Melayu: Jurnal Antarabngsa Dunia Melayu. Jil. 9. Bil.2. 279-294.

Najeeb, M. S. (2013). The history of Sulu. Manila: Bureau of Public Printing.

H.G.Keith. (1980). The monograph of the Brunei museum journal the United States Consul and the Yankee Raja. Brunei Darussalam: The Brunei Museum.

Ian Black. (1983). A gambling style of government the establishment of the chartered company's rule in Sabah 1878-1915. Kuala Lumpur: Oxford University Press.

Irwin, G \& Mohd Nor Ghani dan Noraini Ismail (pnyt.). (1986). Borneo abad kesembilan belas. Kuala Lumpur: Dewan Bahasa dan Pustaka.

Mat Zin Mat Kib. (2017). Sejarah pengurusan pertikaian sempadan antara Britain dan Belanda di pantai timur Borneo Utara dari tahun 1878 hingga 1915. Tesis Doktor Falsafah. Universiti Utara Malaysia.

Mohd Jamil Al-Sufri. (1994). Brunei di tengah-tengah nusantara. Seminar Sejarah Brunei. Bandar Seri Begawan: Pusat Sejarah Brunei. 19-20.

Mohd. Jamil Al-Sufri. (2002). Tarsilah Brunei II zaman kegemilangan dan kemasyuran. Bandar Seri Begawan: Pusat Sejarah Brunei Kementerian Kebudayaan Belia dan Sukan.

Nik Anuar Nik Mahmud. (2001). Tuntutan Filipina ke atas Sabah. Bangi: Universiti Kebangsaan Malaysia.

Noble, L.G. (1977). Philippine policy toward Sabah a claim to independence. Arizona: The University of Arizona Press.

Raffles, T.S. (1830). The history of Java. Vol.2. Singapore: Oxford University Press. Saunders, G. (1994). A history of Brunei. United States of America: New York.

Singh, D.S.R. (2003). The making of Sabah 1865-1941 the dynamics of indigenous society. Kuala Lumpur: Universiti Malaya. 
Dg. Junaidah binti Awang Jambol \& Baszley Bee bin Basrah Bee

Tarling, N. (1971). Britain, the Brookes \& Brunei. Kuala Lumpur: Oxford University Press.

Tregonning, K.G. (2007). Under chartered company rule: North Borneo (18811946). Kuala Lumpur: University Of Malaya.

Wright, L.R. (1998). The origins of British Borneo. Hong Kong: Hong Kong University Press. 